\title{
Soil Carbon Sequestration and Nutrient Status of Different Landuse Types in Knuckles Mountain Range, Sri Lanka
}

\author{
R.P.S.K. Rajapaksha ${ }^{1 *}$, S.D. Saputhanthri ${ }^{2}$, R.R. Ratnayake ${ }^{1}$, S.K. Gunathilake ${ }^{2}$, \\ H.M.S.P. Madawala ${ }^{3}$ \\ ${ }^{I}$ National Institute of Fundamental Studies, Kandy, Sri Lanka \\ ${ }^{2}$ Department of Natural Resources, Sabaragamuwa University, Sri Lanka \\ ${ }^{3}$ Department of Botany, University of Peradeniya, Sri Lanka \\ *krajapaksha58@gmail.com
}

\begin{abstract}
Carbon can be stored in carbon pools for long periods of time through carbon sequestration. Vegetation, soil, ocean and atmosphere are the main sinks for storage of carbon. Among them, soil is a significant $\mathrm{C}$ sink that absorbs more $\mathrm{C}$ than the others. This study aimed at assessing the potential of soil carbon sequestration in selected landuse types in the Knuckles mountain range, where a variety of climatic conditions and landuse types exist. Montane forests (MF), sub-montane forests (SMF), open and sparse forests (OSF) and grasslands (GL) were selected for the study. In addition to $\mathrm{C}$ sequestration, the soil nutrient levels of these landuse types were also assessed. Soil samples were collected from each landuse type from two depths (0-15 cm and 15-30 cm) and analysed for soil moisture content, soil $\mathrm{pH}$ and conductivity, bulk density, total organic carbon (TOC), microbial biomass carbon (MBC), labile carbon (LC), water soluble carbon (WSC) and soil available macro nutrients $\left(\mathrm{NO}^{3-}\right.$, $\mathrm{NH}^{4+}, \mathrm{K}, \mathrm{Ca}, \mathrm{Mg}$ ). Results showed that TOC content was significantly highest in MF and lowest in OSF and GL. The montane forests also recorded higher MBC, LC and WSC contents $(0.14 \%, 715.2 \mathrm{mg} / \mathrm{kg}, 0.46 \%$ respectively) compared to other studied landuse types. Open and Sparse forests showed the highest $\mathrm{NO}^{3-}$ level $(0.89 \mathrm{mg} / \mathrm{kg})$ and the highest $\mathrm{NH}^{4+}$ level $\left(5.79 \times 10^{-5} \mathrm{mg} / \mathrm{kg}\right)$ was recorded in MF. The lowest levels of $\mathrm{NO}^{3-}$ and $\mathrm{NH}^{4+}(0.3 \mathrm{mg} / \mathrm{kg}$ and $2.6 \times 10^{-5} \mathrm{mg} / \mathrm{kg}$ ) were recorded in GL and OSF respectively. Both $\mathrm{Ca}$ and $\mathrm{Mg}$ contents were significantly high in MF. Soil $C$ stocks varied significantly $(p<0.05)$ among these landuse types, where MF recorded the highest soil $\mathrm{C}$ stock of $126.7 \mathrm{t} / \mathrm{ha}$ in top soil layer (0$15 \mathrm{~cm}$ ). Carbon stocks of other three vegetation types SM, OS and GL were 122.4, 98.5 and $99.1 \mathrm{t} / \mathrm{ha}$, respectively. The results showed that MF and SM forests have the greater ability of sequestering $\mathrm{C}$ compared to other studied landuse types in the Knuckles mountain range.
\end{abstract}

Keywords: Soil carbon sequestration, Carbon stocks, Nutrients, Knuckles forest 